\title{
Modification of the effect of nifedipine in the pregnant rat myometrium: The influence of progesterone and terbutaline
}

\author{
Judit Hajagos-Tóth, George Falkay, Róbert Gáspár* \\ Department of Pharmacodynamics and Biopharmacy, Faculty of Pharmacy, University of Szeged, H-6701, P.O. Box 121, Hungary
}

\section{A R T I C L E I N F O}

Article history:

Received 1 July 2009

Accepted 14 August 2009

\section{Keywords:}

Uterine contractility

$\beta_{2}$-adrenoreceptor agonists

Calcium channel blockers

Progesterone

Pregnancy

\begin{abstract}
A B S T R A C T
Aims: The aims of the study were to investigate the effects of nifedipine on potassium chloride ( $\mathrm{KCl}$ )-evoked rat uterine contractions on different days of pregnancy in vitro, and the alterations in the effects of nifedipine on combination with terbutaline or progesterone.

Main methods: In rat myometrial rings taken on different days of pregnancy, rhythmic contractions were evoked with $\mathrm{KCl}$ in an isolated organ bath.

Key findings: The relaxing effect of nifedipine was most expressed in the $25 \mathrm{mM} \mathrm{KCl}$-induced uterine contractions, reaching the maximum on the last day of pregnancy (day 22). This effect was decreased by progesterone pretreatment in vivo. Synergism was observed in the uterus-relaxing effect of nifedipine + terbutaline, though the extent of potentiation depended on the sequence of administration of the two compounds. When terbutaline was added first in a single dose, the maximal inhibitory effect of nifedipine was lower. This decrease in the inhibition was suspended by a $\mathrm{Ca}^{2+}$-poor buffer, indicating the role of $\mathrm{Ca}^{2+}$ channel activating effect of terbutaline.

Significance: It is concluded that the uterus-relaxing effect of nifedipine is weakened by progesterone and may be enhanced by low concentrations of $\beta$-mimetics. However, the administration of terbutaline cannot precede the administration of nifedipine.
\end{abstract}

(C) 2009 Elsevier Inc. All rights reserved.

\section{Introduction}

Uterine contractility is generated by contractions of the myometrial smooth muscle cells that comprise most of the myometrial layer of the uterine wall (Bursztyn et al. 2007). Depolarization of the cell membrane initiates calcium ion $\left(\mathrm{Ca}^{2+}\right)$ entry into the cells through voltage-operated $\mathrm{Ca}^{2+}$ channels, leading to increase in the intracellular $\mathrm{Ca}^{2+}$ concentration $\left(C_{C a, i}\right)$ and muscle contraction (Noble et al. 2009; Dolphin 2006).

The $\mathrm{Ca}^{2+}$ channels are complex proteins composed of five distinct subunits encoded by multiple genes (Catterall et al. 2005). It was demonstrated that the uterine smooth muscle possesses $\alpha_{1 \mathrm{c} \text {-short }}$ and $\alpha_{1 \text { c-long }}$ isoforms (Helguera et al. 2002). Dihydropyridine compounds, such as nifedipine bind to the inside of the voltage-gated L-type channels, inhibiting the action potential and the contractility. The dihydropyridines are the most potent inhibitors of uterine tension development among the $\mathrm{Ca}^{2+}$ entry blockers and are therefore of considerable interest for both therapeutic and experimental purposes (Garfield 1990). Nifedipine and its analogs have recently been considered as tools for tocolytic therapy (Moynihan et al. 2008; Oei 2006). To date, the changes in myometrial contractility to nifedipine by pregnancy have not been investigated.

\footnotetext{
* Corresponding author. Tel.: +36 62 341974; fax: +36 62545567.

E-mail addresses: judittoth@pharm.u-szeged.hu (J. Hajagos-Tóth), falkay@pharm.u-szeged.hu (G. Falkay), gaspar@pharm.u-szeged.hu (R. Gáspár).
}

$\beta$-adrenergic stimulants produce relaxation of the smooth muscle by raising the level of intracellular cyclic AMP. Progesterone pretreatment increases the expression of the $\beta_{2}$-adrenergic receptor (AR) during pregnancy and alters the effects of $\beta_{2}$-AR agonists on the pregnant myometrium; progesterone and its derivatives have been considered as drugs against premature labor (Gálik et al. 2008; Mackenzie et al. 2006). The addition of a $\beta$-agonist to a $\mathrm{Ca}^{2+}$ antagonist might be expected to increase the effect of the $\mathrm{Ca}^{2+}$ antagonist (Triggle 1978; Lever et al. 1984). The effects of combinations of $\beta_{2}$-AR agonists and $\mathrm{Ca}^{2+}$ channel blockers have previously been investigated in the isolated trachea. It was shown that both isradipine and nifedipine potentiated the relaxant action of terbutaline and salmeterol, respectively (Thirstrup et al. 1997).

One of the aims of the present study was an in vitro investigation of the effects of nifedipine on the potassium chloride $(\mathrm{KCl})$-evoked rat uterine contractions on different days of pregnancy in rat. As a further aim, we set out to alter the effect of nifedipine by applying a combination with terbutaline or progesterone.

\section{Materials and methods}

All experiments involving animal subjects were carried out with the approval of the Hungarian Ethical Committee for Animal Research (registration number: IV/1758-2/2008). 
Mating of the animals

Mature female (180-200 g) and male (240-260 g) Sprague-Dawley rats were mated in a special mating cage. A metal door, which was movable by a small electric engine, separated the rooms for the male and female animals. A timer controlled the function of the engine. Since rats are usually active at night, the separating door was opened before dawn. Within 4-5 h after the possibility of mating, vaginal smears were taken from the female rats and a sperm search was performed under a microscope at a magnification of 1200 times. If the smear proved positive, or if smear taking was impossible because of an existing vaginal sperm plug, the female rats were separated and were regarded as firstday pregnant animals.

\section{Isolated organ studies}

\section{Uterus preparation}

Uteri were removed from rats (250-350 g) on day 15, 18, 20 or 22 of pregnancy. Muscle rings $5 \mathrm{~mm}$ long were sliced from the uterine horns and mounted vertically in an organ bath containing $10 \mathrm{ml}$ de Jongh solution (composition: $137 \mathrm{mM} \mathrm{NaCl}, 3 \mathrm{mM} \mathrm{KCl}, 1 \mathrm{mM} \mathrm{CaCl}_{2}$, $1 \mathrm{mM} \mathrm{MgCl}, 12 \mathrm{mM} \mathrm{NaHCO}, 4 \mathrm{mM} \mathrm{NaH} \mathrm{PO}_{4}, 6 \mathrm{mM}$ glucose, $\mathrm{pH}=7.4)$. The organ bath was maintained at $37^{\circ} \mathrm{C}$ and carbogen $(95 \%$ $\mathrm{O}_{2}+5 \% \mathrm{CO}_{2}$ ) was bubbled through it. After mounting, the rings were equilibrated for about $1 \mathrm{~h}$ before the experiments were undertaken, with a solution change every $15 \mathrm{~min}$. The initial tension of the preparation was set to about $1.25 \mathrm{~g}$, which was relaxed to about $0.5 \mathrm{~g}$ at the end of equilibration. The tension of the myometrial rings was measured with a gauge transducer (SG-02; Experimetria Ltd., Budapest, Hungary) and recorded with a SPEL Advanced ISOSYS Data Acquisition System (Experimetria Ltd., Budapest, Hungary).

\section{Nifedipine studies}

Contractions were elicited with $25 \mathrm{mM}$ or $100 \mathrm{mM} \mathrm{KCl}$, and noncumulative dose-response curves were constructed in each experiment in the presence of nifedipine $\left(10^{-11}-10^{-6} \mathrm{M}\right)$ (Sigma-Aldrich, Budapest, Hungary). Following the addition of each concentration of nifedipine, recording was performed for $300 \mathrm{~s}$. Concentration-response curves were fitted, and areas under curves (AUCs) were evaluated and analyzed statistically with the Prism 4.0 (Graphpad Software Inc. San Diego, CA, USA) computer program. From the AUC values, the maximal inhibitory effect of nifedipine on a given day of pregnancy $\left(E_{\max }\right)$ and the concentration of nifedipine eliciting $50 \%$ of the maximal inhibition of uterine contraction $\left(\mathrm{EC}_{50}\right)$ were calculated. For statistical evaluations, data were analyzed by the ANOVA Neuman-Keuls test.

\section{Nifedipine combination with terbutaline}

Uteri were removed from rats (250-350 g) on day 22 of pregnancy and mounted vertically in the organ bath as described above. Contractions were elicited with $25 \mathrm{mM} \mathrm{KCl}$, and cumulative doseresponse curves were constructed in each experiment in the presence of nifedipine $\left(10^{-11}-10^{-6} \mathrm{M}\right)$ and terbutaline (Sigma-Aldrich, Budapest, Hungary) $\left(10^{-7} \mathrm{M}\right)$ or terbutaline $\left(10^{-10}-10^{-4} \mathrm{M}\right)$ and nifedipine $\left(10^{-7} \mathrm{M}\right)$. The effects of the nifedipine + terbutaline combination were also investigated in the absence of $\mathrm{Ca}^{2+}$ ion in vitro. De Jongh solution containing $0.5 \mathrm{mM} \mathrm{Ca}^{2+}$ ion was used to induce a low $\mathrm{Ca}^{2+}$ environment. After the equilibration period, the normal De Jongh solution was changed to the low $\mathrm{Ca}^{2+}$-containing solution. The $E_{\max }$ and $\mathrm{EC}_{50}$ values of the curves obtained with the combinations were calculated. For statistical evaluations, data were analyzed through the unpaired $t$ test.

Progesterone treatment

The progesterone treatment of the pregnant animals was started on day 15 of pregnancy. Progesterone was dissolved in corn oil and injected subcutaneously every day up to day 21 in a dose of $0.5 \mathrm{mg} /$ $0.1 \mathrm{ml}$. On day 22, the uterine samples were collected and the contractility studies $(25 \mathrm{mM} \mathrm{KCl})$ were carried out with nifedipine as described above.

\section{Results}

The $25 \mathrm{mM}$ and $100 \mathrm{mM} \mathrm{KCl}$-stimulated uterine contractions were inhibited concentration-dependently by nifedipine in the range of $10^{-11}$ $10^{-5} \mathrm{M}$ (Fig. 1a, b). As concerns the contractions induced by $100 \mathrm{mM} \mathrm{KCl}$, the calculated $\mathrm{EC}_{50}$ was lower on day 18 than on day 15 (Table 1 ), but there were no changes on the other days. There were significant changes in $E_{\max }$ on days 18,20 and 22 as compared that on day 15 . In the presence of $25 \mathrm{mM} \mathrm{KCl}$, the maximal relaxing effect of nifedipine was significantly greater on days 20 and 22 than on day 15 . There were no significant changes in $\mathrm{EC}_{50}$ (Table 2).

The progesterone pretreatment decreased the maximal inhibitory effect of nifedipine on day 22 and more than doubled its $\mathrm{EC}_{50}$ (Fig. 2, Table 3).

The concentration-response curves for nifedipine in the presence of $10^{-7} \mathrm{M}$ terbutaline were shifted to the left and a decrease in the maximal inhibitory effect was observed (Fig. 3a, Table 4a). In the presence of $0.5 \mathrm{mM} \mathrm{Ca}^{2+}\left(\mathrm{Ca}^{2+}\right.$-poor buffer $)$, terbutaline did alter the effect of nifedipine (Fig. 3b, Table 4b).
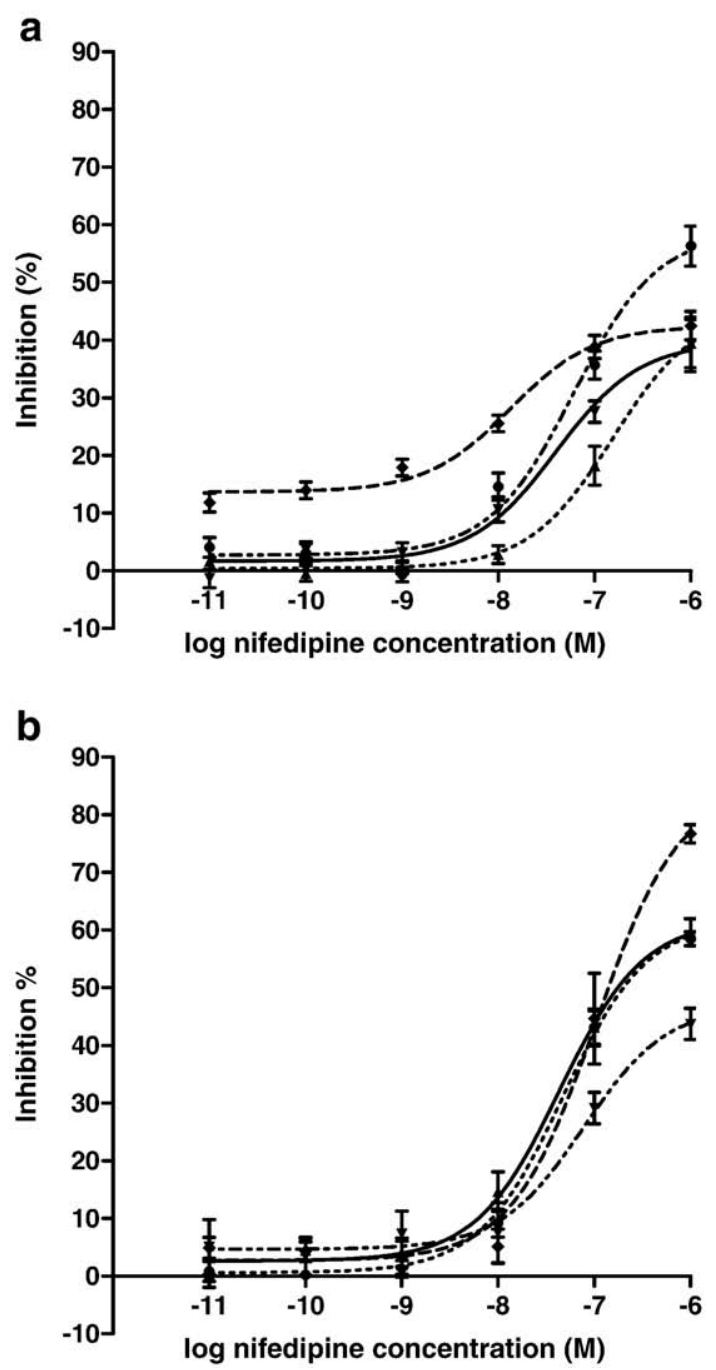

Fig. 1. Inhibitory effect of nifedipine on contractions evoked by $100 \mathrm{mM}$ (a) and $25 \mathrm{mM}$ (b) $\mathrm{KCl}$ in isolated pregnant rat uteri in vitro on different days of pregnancy. $\bullet$ day $15, \boldsymbol{\Delta}$ day $18, \boldsymbol{\nabla}$ day 20 , day 22 
Table 1

$\mathrm{EC}_{50}$ and $E_{\max }$ values of curves of uterine relaxation induced by nifedipine $\left(10^{-11}-10^{-6} \mathrm{M}\right)$ in the presence of $100 \mathrm{mM} \mathrm{KCl}$.

\begin{tabular}{lll}
\hline Day of pregnancy & $\mathrm{EC}_{50}(\mathrm{M} \pm$ S.E.M. $)$ & $E_{\max }(\% \pm$ S.E.M. $)$ \\
\hline 15 & $6.8 \times 10^{-8} \pm 1.1 \times 10^{-8}$ & $62.7 \pm 2.7$ \\
18 & $1.5 \times 10^{-7} \pm 4.7 \times 10^{-8^{* * *}}$ & $46.9 \pm 3.6^{*}$ \\
20 & $3.9 \times 10^{-8} \pm 1.1 \times 10^{-8} \mathrm{~ns}$ & $39.6 \pm 4.4^{*}$ \\
22 & $1.2 \times 10^{-8} \pm 1.1 \times 10^{-8} \mathrm{~ns}$ & $41.7 \pm 4.3^{*}$ \\
\hline
\end{tabular}

On each day, the level of significance relates to the comparison with the value on day 15 S.E.M.: standard error of the mean; ns: not significant, ${ }^{*} p<0.05,{ }^{* * *} p<0.001$.

The concentration-response curves for terbutaline in the presence of $10^{-7} \mathrm{M}$ nifedipine were also shifted to the left, but the this shift was greater than that of the nifedipine curve by terbutaline. Nifedipine also significantly increased the $E_{\max }$ of terbutaline (Fig. 4a, Table 5a). In the $\mathrm{Ca}^{2+}$-poor buffer, the presence of nifedipine increased the $\mathrm{EC}_{50}$ of terbutaline, but did not alter its $E_{\max }$ (Fig. $4 \mathrm{~b}$, Table $5 \mathrm{~b}$ ).

\section{Discussion}

High $\mathrm{K}^{+}$stimulation, which provokes membrane depolarization and uterine contractions, is the most common method for the introduction of $\mathrm{Ca}^{2+}$ into cells without receptor stimulation. There are a number of data relating to the use of different concentrations of $\mathrm{KCl}$ (from low to high $\mathrm{K}^{+}$) to evoke contraction in vitro by opening voltage-gated $\mathrm{Ca}^{2+}$ channels, though it is not clear which of these concentrations causes rhythmic contractions of the uterus providing an appropriate model for investigation of the pregnant uterusrelaxing effects.

We found that in the presence of $25 \mathrm{mM} \mathrm{KCl}$ the uterine contractions were rhythmic and the relaxing effect of nifedipine was very high on the last day of pregnancy. With $100 \mathrm{mM} \mathrm{KCl}$, however, the contractions became spastic and the inhibitory action of nifedipine was highest on day 15 , but was later quite weak. These results led us to conclude that stimulation with $25 \mathrm{mM} \mathrm{KCl}$ is much more appropriate for investigations of the action of the $\mathrm{Ca}^{2+}$ channel blocker nifedipine. As the relaxing effect of nifedipine was highest on the last day of pregnancy, further experiments were carried out on day 22.

It was earlier demonstrated that the myometrial dihydropyridine binding is increased more than 3-fold at the end of pregnancy in the rat (Mershon et al. 1994), and this result was supported by our findings. However, others found that the protein expressions and mRNA levels of the pore-forming $\alpha_{1}$-subunits of the $\mathrm{Ca}^{2+}$ channels were not altered by pregnancy either in rats or in humans (Batra and Popper 1989 Helguera et al. 2002). It is known that the $\mathrm{Ca}_{\mathrm{v}} 1.2$ channels possess splice variants in the cardiac muscle, which have different pharmacological and electrophysiological properties (Liao et al. 2005). So far, such variants have not been discovered in the myometrium, but the apparent contradictions observed between the above-mentioned papers and our result might be explained by the existence of putative channel splice variants in the pregnant uterus.

The activity of the $\mathrm{Ca}_{\mathrm{v}} 1.2$ channel is regulated by several factors (Kobayashi et al. 2007). In our study, two of them were investigated with regard to how to influence the uterus-relaxing effect of nifedipine in vitro. Progesterone is regarded as a preventive drug

\section{Table 2}

$\mathrm{EC}_{50}$ and $E_{\max }$ values of curves of uterine relaxation induced by nifedipine $\left(10^{-11}-10^{-6} \mathrm{M}\right)$ in the presence of $25 \mathrm{mM} \mathrm{KCl}$ on different days of pregnancy.

\begin{tabular}{lcl}
\hline Day of pregnancy & $\mathrm{EC}_{50}(\mathrm{M} \pm$ S.E.M. $)$ & $E_{\max }(\% \pm$ S.E.M. $)$ \\
\hline 15 & $4.8 \times 10^{-8} \pm 1.4 \times 10^{-7}$ & $61.7 \pm 1.9$ \\
18 & $4.7 \times 10^{-8} \pm 1.1 \times 10^{-8} \mathrm{~ns}$ & $61.8 \pm 2.9 \mathrm{~ns}$ \\
20 & $7.4 \times 10^{-8} \pm 2.4 \times 10^{-8} \mathrm{~ns}$ & $47.0 \pm 3.1^{* *}$ \\
22 & $1.03 \times 10^{-7} \pm 3.6 \times 10^{-8} \mathrm{~ns}$ & $84.6 \pm 2.6^{* * *}$ \\
\hline
\end{tabular}

On each day, the level of significance relates to the comparison with the value on day 15 S.E.M.: standard error of the mean; ns: not significant, ${ }^{* *} p<0.01,{ }^{* * *} p<0.001$.

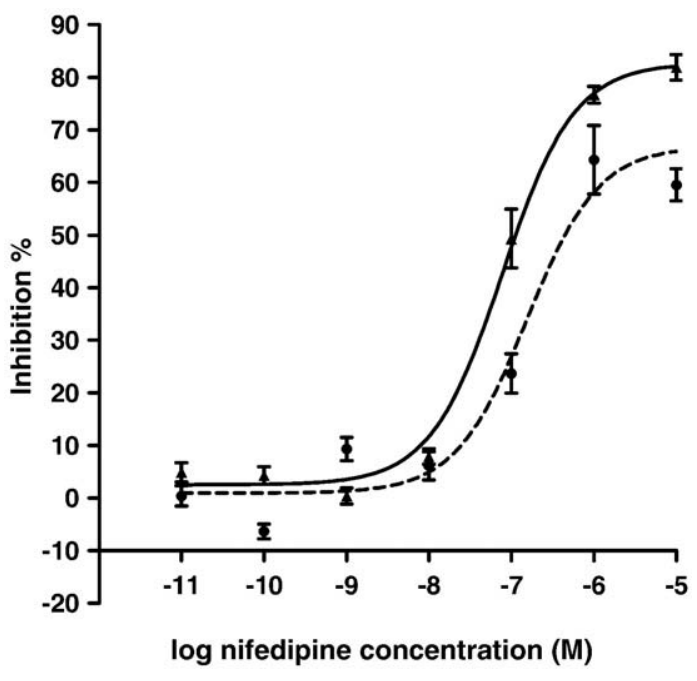

Fig. 2. Inhibitory effect of nifedipine on contractions evoked by $25 \mathrm{mM} \mathrm{KCl}$ with or without progesterone pretreatment on day 22. $\boldsymbol{\Delta}$ nifedipine, $\bullet$ after progesterone pretreatment.

against premature labor, especially in late-preterm birth (Borna and Sahabi 2008). Unfortunately, the in vivo progesterone pretreatment decreased the maximal inhibitory effect of nifedipine and increased its $\mathrm{EC}_{50}$. The uterine smooth muscle possesses $\alpha_{1 \mathrm{C} \text {-long }}$ and $\alpha_{1 \mathrm{C} \text {-short }}$ isoforms of the L-type $\mathrm{Ca}^{2+}$ channel. In the presence of the long isoform, the channel has lower activity than with the short isoform. In the pregnant rat uterus, progesterone and estrogen enhance the expressions of the $\alpha_{1 \text { c-long }}$ and $\alpha_{1 \text { c-short }}$ isoforms, respectively, of the L-type $\mathrm{Ca}^{2+}$ channels (Helguera et al. 2002). These facts explain why progesterone pretreatment worsened the relaxing effect of nifedipine. Accordingly we presumed that a $\mathrm{Ca}^{2+}$ channel blocker + progesterone combination might not have any benefit in clinical practice.

The other investigated factor which regulates the $\mathrm{Ca}_{\mathrm{v}} 1.2$ channel was the $\beta_{2}$-adrenergic system. We found synergism in the uterusrelaxing effect of nifedipine and the $\beta_{2}$-AR agonist terbutaline, although the extent of potentiation depended on the sequence of administration of the two compounds. When terbutaline was added first in a single dose, synergism was found in $\mathrm{EC}_{50}$ (the nifedipine curve was shifted to the left), but the maximal inhibitory effect of nifedipine was lower. When nifedipine was administered first, the relaxing effect of terbutaline was obviously stronger.

It is known that stimulation of $\beta_{2}$-ARs activates G-proteins and increases the intracellular cAMP level. cAMP activates protein kinase A the activated form of which phosphorylates the $\mathrm{Ca}_{\mathrm{v}} 1.2$ channels. This mechanism is well known in the heart muscle (Kamp and Hell 2000) and it is very probably similar in the pregnant myometrium. The entry of the $\mathrm{Ca}^{2+}$ into the cells through the voltage-gated $\mathrm{Ca}^{2+}$ channel is one of the crucial factors in the generation of smooth muscle contraction. Terbutaline possibly activates the $\mathrm{Ca}_{\mathrm{v}} 1.2$ channels and decreases the maximal relaxing effect of nifedipine. The resultant effect of the increase of cAMP level and activation of $\mathrm{Ca}_{\mathrm{v}} 1.2$ channels causes a weaker smooth muscle relaxation. In the opposite case, when nifedipine is administered first, the $\mathrm{Ca}_{\mathrm{v}} 1.2$ channels are blocked; hence, there is only a low possibility that terbutaline can activate them.

Table 3

$\mathrm{EC}_{50}$ and $E_{\max }$ values of curves of uterine relaxation induced by nifedipine $\left(10^{-11}-10^{-5} \mathrm{M}\right)$ in the presence of $25 \mathrm{mM} \mathrm{KCl}$ on day 22 after progesterone pretreatment.

\begin{tabular}{lll}
\hline & $\mathrm{EC}_{50}(\mathrm{M} \pm$ S.E.M. $)$ & $E_{\max }(\% \pm$ S.E.M. $)$ \\
\hline Nifedipine & $9.7 \times 10^{-8} \pm 2.8 \times 10^{-8}$ & $87.3 \pm 2.2$ \\
Nifedipine + progesterone & $2.8 \times 10^{-7} \pm 4.9 \times 10^{-8^{* * *}}$ & $81.9 \pm 8.7 \mathrm{~ns}$ \\
\hline
\end{tabular}

S.E.M.: standard error of the mean; ns: not significant, ${ }^{* *} p<0.01$. 
a

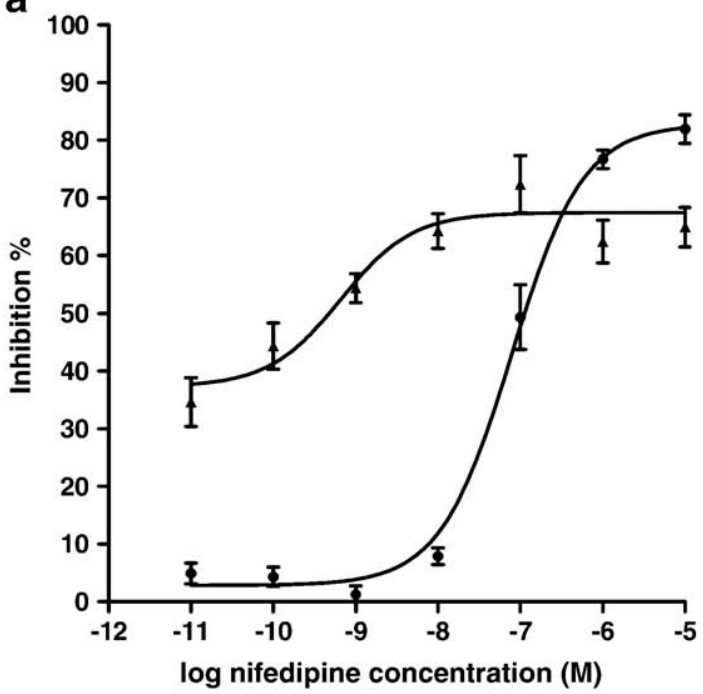

b

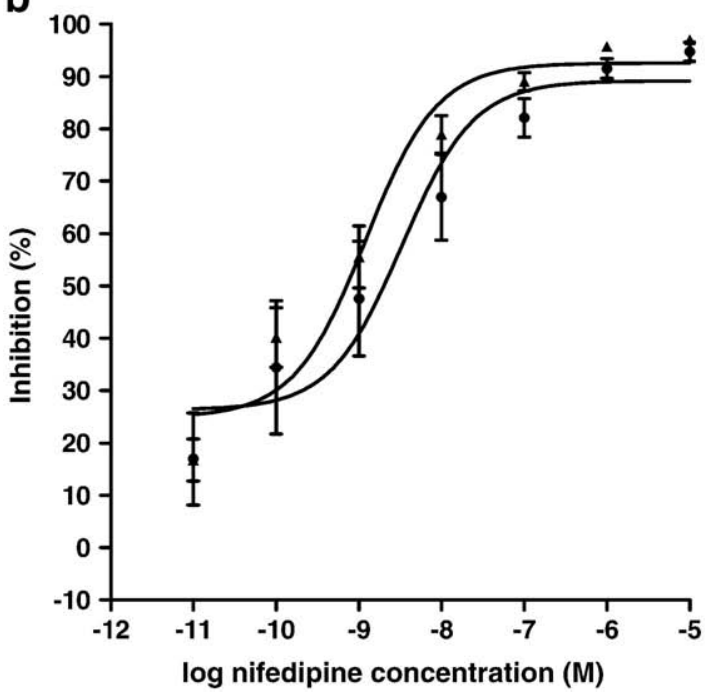

Fig. 3. Effect of the nifedipine + terbutaline combination on the $25 \mathrm{mM} \mathrm{KCl-evoked}$ contractions in vitro on day 22. nifedipine; $\boldsymbol{\Delta}$ nifedipine and terbutaline $\left(10^{-7} \mathrm{M}\right)$ in $1 \mathrm{mM} \mathrm{Ca}^{2+}$-containing buffer; $\square$ nifedipine; $\Delta$ nifedipine + terbutaline $\left(10^{-7} \mathrm{M}\right)$ in $0.5 \mathrm{mM} \mathrm{Ca}^{2+}$-containing buffer.

To check on the above-mentioned hypothesis, the synergism between the two compounds was investigated in $\mathrm{Ca}^{2+}$-poor buffer. $\mathrm{A}$ $\mathrm{Ca}^{2+}$-poor environment theoretically decreases the terbutalineinduced $\mathrm{Ca}^{2+}$ influx and may alter the extent of the synergism. The $\mathrm{Ca}^{2+}$-poor environment shifted the nifedipine dose-response curve

Table 4

$\mathrm{EC}_{50}$ and $E_{\max }$ values of curves of uterine relaxation induced by the nifedipine + terbutaline combination in the presence of $25 \mathrm{mM} \mathrm{KCl}$ on day 22 at $1 \mathrm{mM}$ (a), $0.5 \mathrm{mM}$ (b) $\mathrm{Ca}^{2+}$.

\begin{tabular}{lll}
\hline & $\mathrm{EC}_{50}(\mathrm{M} \pm$ S.E.M. $)$ & $E_{\max }(\% \pm$ S.E.M. $)$ \\
\hline a & & \\
Nifedipine & $7.9 \times 10^{-8} \pm 1.3 \times 10^{-8}$ & $82.9 \pm 1.4$ \\
Nifedipine + terbutaline $\left(10^{-7} \mathrm{M}\right)$ & $7.0 \times 10^{-10} \pm 1.2 \times 10^{-10^{*}}$ & $68.0 \pm 4.5^{* *}$ \\
& & \\
$\mathrm{~b}$ & & \\
Nifedipine & $4.0 \times 10^{-9} \pm 2.1 \times 10^{-9}$ & $89.2 \pm 2.1$ \\
Nifedipine + terbutaline $\left(10^{-7} \mathrm{M}\right)$ & $1.6 \times 10^{-9} \pm 7.3 \times 10^{-10} \mathrm{~ns}$ & $92.6 \pm 0.4 \mathrm{~ns}$ \\
\hline
\end{tabular}

The level of significance relates to the comparison with the values for nifedipine and terbutaline. S.E.M.: standard error of the mean; ns: not significant, ${ }^{*} p<0.05,{ }^{* *} p<0.01$. a

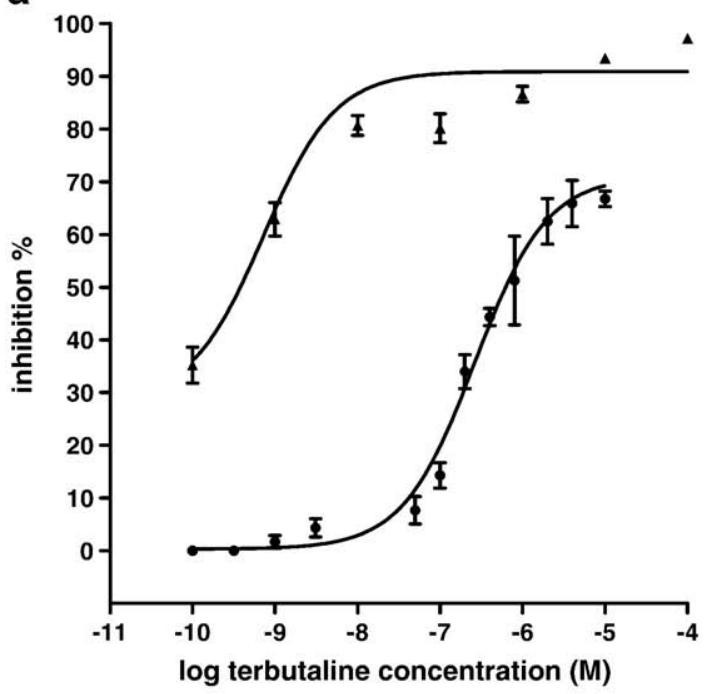

b

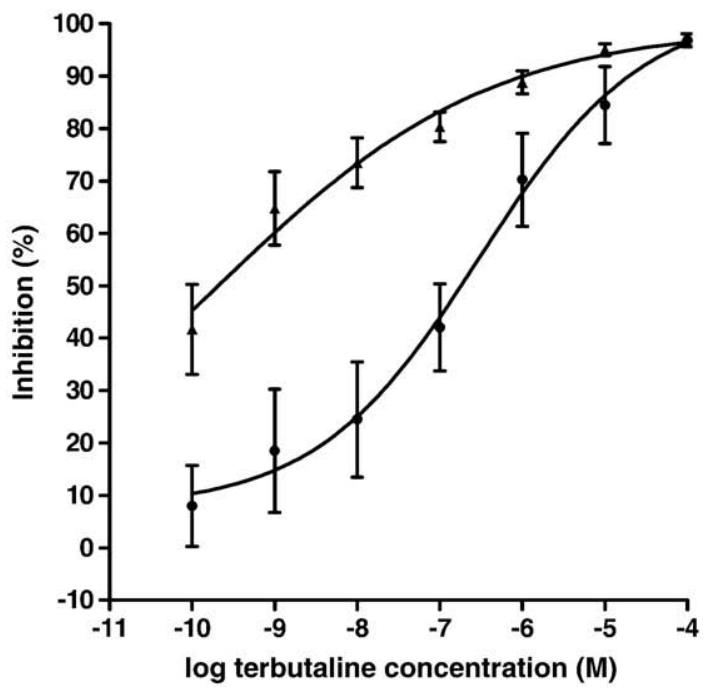

Fig. 4. Effect of the nifedipine + terbutaline combination on the $25 \mathrm{mM} \mathrm{KCl}$-chloride evoked contractions in vitro on day 22. (a) $\mathbf{a}$ terbutaline; $\boldsymbol{\Delta}$ terbutaline + nifedipine $\left(10^{-7} \mathrm{M}\right)$ (b) in $0.5 \mathrm{mM} \mathrm{Ca}{ }^{2+}$-containing buffer ( $\square$ terbutaline; $\Delta$ terbutaline + nifedipine $\left(10^{-7} \mathrm{M}\right)$.

to the left, and the maximal inhibitory effect of nifedipine was so high that its effect could not be enhanced by terbutaline. In contrast, the $\mathrm{Ca}^{2+}$-poor environment shifted the terbutaline dose-response curve to the left, but nifedipine was able to enhance the shift. However, it could not increase the maximal uterus-relaxing effect of terbutaline,

Table 5

$\mathrm{EC}_{50}$ and $E_{\max }$ values of curves of uterine relaxation induced by the nifedipine + terbutaline combination in the presence of $25 \mathrm{mM} \mathrm{KCl}$ on day 22 at $1 \mathrm{mM}$ (a), $0.5 \mathrm{mM}$ (b) $\mathrm{Ca}^{2+}$.

\begin{tabular}{lcl}
\hline & $\mathrm{EC}_{50}(\mathrm{M} \pm$ S.E.M. $)$ & $E_{\max }(\% \pm$ S.E.M. $)$ \\
\hline a & & \\
Terbutaline & $6.9 \times 10^{-7} \pm 1.7 \times 10^{-7}$ & $74.6 \pm 2.8$ \\
Terbutaline + nifedipine $\left(10^{-7} \mathrm{M}\right)$ & $8.3 \times 10^{-10} \pm 1.6 \times 10^{-10^{* * *}}$ & $90.8 \pm 0.8^{* * *}$ \\
& & \\
b & & \\
Terbutaline & $1.5 \times 10^{-7} \pm 1.6 \times 10^{-10}$ & $97.6 \pm 1.1$ \\
Terbutaline + nifedipine $\left(10^{-7} \mathrm{M}\right)$ & $5.3 \times 10^{-9} \pm 2.1 \times 10^{-9^{* *}}$ & $95.4 \pm 1.1 \mathrm{~ns}$
\end{tabular}

The level of significance relates to the comparison with the values for nifedipine and terbutaline. S.E.M.: standard error of the mean; ns: not significant, ${ }^{* *} p<0.01$, $* * * p<0.001$ 
possibly because of the very strong blocking effect of the $\beta$-mimetic. These results indicate that, in a $\mathrm{Ca}^{2+}$-poor environment, terbutaline is not able to worsen the maximal effect of nifedipine, which suggests the role of the $\mathrm{Ca}^{2+}$ inflow in the weakening effect of terbutaline.

\section{Conclusions}

In the light of our results, we can conclude that the uterus-relaxing effect of nifedipine is markedly increased on the last day of pregnancy in the rat. In vivo progesterone treatment reduces the relaxant effect of nifedipine on contracted uterine muscle. The combination of nifedipine + terbutaline may be beneficial to enhance the myometrial relaxation, but our results indicate that the administration of terbutaline cannot precede that of nifedipine.

\section{Acknowledgement}

This work was supported by a Hungarian OTKA Research Grant (K62707).

\section{References}

Batra SC, Popper LD. Characterization of membrane calcium channels in non-pregnant and pregnant human uterus. Gynaecologic and Obstetric Investigation 27, 57-61, 1989.

Borna S, Sahabi N. Progesterone for maintained tocolytic therapy after threatened preterm labour: a randomised controlled trial. The Australian and New Zealand Journal of Obstetric and Gynaecology 48, 58-63, 2008.

Bursztyn L, Eytan O, Jaffa AJ, Elad D. Mathematical model of excitation-contraction in a uterine smooth muscle cell. American Journal of Physiology. Cell Physiology 292, C1816-C1829, 2007.

Catterall WA, Perez-Reyes E, Snutch TP, Striessnig J. International Union of Pharmacology. XLVIII. Nomenclature and structure-function relationships of voltage-gated calcium channels. Pharmacological Reviews 57, 411-425, 2005.

Dolphin AC. A short history of voltage-gated calcium channels. British Journal of Pharmacology 147, S56-S62, 2006.
Gálik M, Gáspár R, Kolarovszki-Sipiczki Z, Falkay G. Gestagen treatment enhances the tocolytic effect of salmeterol in hormone-induced preterm labour in the rat in vivo. American Journal of Obstetric and Gynaecology 198 (3) 319. e1-319. e5, 2008.

Garfield RE. Uterine Contractility, Mechanisms of Control, Serono Symposia, Norwell, Massachusetts. (Chapter 2), 1990.

Helguera G, Olcese R, Song M, Toro L, Stefani E. Tissue-specific regulation of $\mathrm{Ca}^{2+}$ channel protein expression by sex hormones. Biochimica et Biophysica Acta 1569 59-66, 2002.

Kamp TJ, Hell JW. Regulation of cardiac L-type calcium channels by protein kinase A and protein kinase C. Circulation Research 87, 1095-1102, 2000.

Kobayashi T, Yamada Y, Fukao M, Tsutsuura M, Tohse N. Regulation of $\mathrm{Ca}_{\mathrm{v}} 1.2$ current: interaction with intracellular molecules. Journal of Pharmacological Sciences 103, 347-353, 2007.

Lever AML, Corris PA, Gibson GJ. Nifedipine enhances the bronchodilator effect of salbutamol. Thorax 39, 576-578, 1984.

Liao P, Yong TF, Liang MC, Yue DT, Soong TW. Splicing for alternative structures of $\mathrm{Ca}_{\mathrm{v}} 1.2 \mathrm{Ca}^{2+}$ channels in cardiac and smooth muscles. Cardiovascular Research 68, 197-203, 2005.

Mackenzie R, Walker M, Armson A, Hannah ME. Progesterone for the prevention of preterm birth among women at increased risk: a systematic review and metaanalysis of randomized controlled trials. American Journal of Obstetric and Gynaecology 194, 1234-1242, 2006.

Mershon JL, Mikala G, Schwartz A. Changes in the expression of the L-type voltagedependent calcium channel during pregnancy and parturition in the rat. Biology of Reproduction 51, 993-999, 1994.

Moynihan AT, Smith TJ, Morrison JJ. The relaxant effect of nifedipine in human uterine smooth muscle and the $\mathrm{BK}_{\mathrm{Ca}}$ channel. American Journal of Obstetric and Gynaecology 198, 237.e1-237.e8, 2008.

Noble K, Matthew A, Burdyga T, Wray S. A review of recent insights into the role of the sarcoplasmic reticulum and Ca entry in uterine smooth muscle. European Journal of Obstetrics and Gynecology and Reproductive Biology 144S, S11-S19, 2009.

Oei SG. Calcium channel blockers for tocolysis: a review of their role and safety following reports of serious adverse events. European Journal of Obstetric and Gynaecology 126, 137-145, 2006.

Thirstrup S, Nielsen-Kudsk F, Dahl F. In vitro studies on the interactions of $\beta_{2}$ adrenoreceptor agonists, methylxantienes, $\mathrm{Ca}^{2+}$-channel blockers, $\mathrm{K}^{+}$-channel openers and other airway smooth muscle relaxants in isolated guinea-pig trachea. European Journal of Pharmacology 326, 191-200, 1997.

Triggle DJ. Calcium antagonists: basic chemical and pharmacological aspects. In: Weiss, GB (Ed.), New perspectives on calcium antagonists. InAmerican Physiological Society, Bethesda, pp. 1-18, 1978. 